\title{
PEMANFAATAN BARANG BEKAS MENJADI KERAJINAN TANGAN GUNA MENINGKATKAN KREATIVITAS MASYARAKAT DESA PAOWAN
}

\author{
Indah Lestari Setiorini \\ Indahlestarikurniawan1@gmail.com
}

Fakultas Keguruan dan Ilmu Pendidikan,Universitas Abdurachman Saleh Situbondo

\begin{abstract}
The use of plastic in much kind of products has become unstoppable. It certainly impact on polluting the environment because plastic waste will require the immense period of time to degrade naturally. In order to reduce the plastic waste, Family welfare movement in Paowan has an initiave to train the employees to process plastic bottle waste into table lamp which functional and worth aesthetically. This research is the result of the outer implementation of PKM which use qualitative research method to analyze and qualify the research. Experimentative method is applied for the training and experiment program to make various derivative products made from plastic waste, by considering the design aspects such as: shape, size, function, and color. The results of the program acknowledges that the plastic waste combined with pipe,spon and box, with regards of design aspects becoming worth sellingvarious functional product. The real and practical sustainable social program such as PKM hopefully will strengthen the bond among education institution and the society
\end{abstract}

Keywords: plastic waste, course, added value product, increasing society welfare

\section{PENDAHULUAN}

Dewasa ini, sampah menjadi salah satu permasalahan yang cukup sulit di tangani di Indonesia. Hal ini terjadi karena kebiasaan masyarakatnya sebagai konsumen yang selalu menghasilkan sampah terutama plastik pada setiap pemakaian produk. Seiring dengan perkembangan teknologi kebutuhan plastik terus meningkat, plastik merupakan bahan anorganik buatan yang tersusun dari bahan-bahan kimia yang sukar diuraikan sehingga berbahaya bagi lingkungan. Sampah tersebut menjadi permasalahan lingkungan karena kuantitas maupun tingkat bahayanya mengganggu kelangsungan makhluk hidup. Oleh karena itu dengan mengubah sampah plastik menjadi barang yang dapat digunakan kembali dapat membantu mengurangi pencemaran lingkungan.

Kreativitas pemanfaatan sampah plastik menjadi kerajinan tangan adalah solusi yang cukup baik untuk mengubah barang bekas menjadi menjadi barang yang berguna kembali, bahkan memiliki nilai jual serta dapat dikreasikan menjadi barang yang mempunyai nilai estetika. Kreativitas dalam diri seseorang dapat ditumbuhkan melalui banyak cara, salah satunya yaitu dengan membuat kerajinan tangan. Sampah plastik dapat dibuat kerajinan tangan seperti tas belanja, hiasan kamar, dompet, lampu hias, tempat pensil, keranjang, dan lain lain. 
Pemanfaatan barang bekas dapat dijadikan sebagai alternative bagi masyarakat Desa Paowan untuk berlaku bijak terhadap sampah sehingga dapat memberikan manfaat baik dari segi penggunaan bahan daur ulang barang bekas maupun untuk peningkatan penghasilan keluarga dengan menjual produk daur ulang yang sudah dihasilkan. Bahan yang digunakan banyak ditemui dilingkungan sekitar sehingga tidak memerlukan biaya besar hanya dengan bermodalkan keterampilan dalam memanfaatkannya.

Khalayak yang dijadikan sasaran kegiatan ini adalah masyarakat Desa Paowan yaitu khususnya ibu-ibu PKK. Desa Paowan merupakan salah satu desa yang terletak di Kecamatan Panarukan Kabupaten Situbondo. Desa ini merupakan desa yang terkenal dengan masyarakatnya yang kreatif dan bekerja keras. Namun rata-rata pendidikan yang ditempuh masyarat di desa tersebut hanya sampai tingkat SMA saja, bahkan ada juga yang hanya sampai tingkah SMP. Di desa Paowan hanya beberapa orang saja yang dapat melanjutkan sekolah ke perguruan tinggi. Hal tersebut dikarenakan kurangnya biaya yang dimiliki oleh masyarakat untuk melanjutkan sekolah ke jenjang yang lebih tinggi.

Rata-rata pekerjaan yang di dominasi oleh Desa Paowan ini petani, buruh dan pedagang karena tingkat lulusannya yang masih rendah sehingga tidak dapat mendapatkan pekerjaan yang lebih baik. Di desa ini juga ada yang berprofesi sebagai guru dan sudah PNS, namun hanya beberapa saja yang memiliki profesi tersebut. Masih banyak masyarakat pengangguran karena sulitnya mencari pekerjaan karena tingkat lulusan yang dimiliki masyarakat tersebut masih rendah.

Di desa Paowan ini juga masih banyak yang belum terlalu memperhatikan kebersihan lingkungan. Sehingga masih banyak masyarakat yang membuang sampah di sambarang tempat. Di desa ini juga belum terdapat tempat pembuangan sampah. Jadi sampah-sampah dari masyarakat hanya bisa dibakar saja oleh masyarakat itu sendiri. Dalam hal tersebut maka dalam program ini dapat melakukan pelatihan yang dapat memanfaatkan barang bekas sebagai kerajian tangan. Karena masih banyak masyarakat pengangguran dan belum sepenuhnya bisa memperhatikan lingkungan, sehingga dalam hal tersebut bisa menyadarkan masyarakat bahwa kebersihan lingkungan itu penting dan sampah yang dapat dimanfaatkan menjadi sesuatu barang yang bernilai. 
Kurangnya kreatifitas dan keterampilan pada masyarakat terjadi karena kurangnya kesadaran serta pengetahuan tentang pemanfaatan barang bekas ataupun sampah yang dapat di daur ulang kembali. Oleh karena itu, program ini menawarkan solusi untuk mengatasi masalah tersebut, yaitu dengan memberikan pelatihan sekaligus pengetahuan terhadap masyarakat Desa Paowan agar lebih kreatif dan terampil terutama dalam mengolah kembali sampah plastik yang terdapat di sekitar lingkungan tempat tinggal mereka menjadi kerajinan tangan yang bermanfaat. Dengan pemanfaatan sampah plastik untuk dijadikan kerajinan tangan juga dapat mengurangi masalah pencemaran lingkungan di kabupaten Situbondo.

\section{METODE PELAKSANAAN}

Program kreatifitas mahasiswa ini akan dilaksanakan selama 2 bulan yang dimulai sejak bulan awal pendanaan program PKM tahap awal cair. Program ini dilaksanakan setiap hari Selasa dengan durasi pelatihan 120 menit tiap pertemuan. Kegiatan ini bertempat di Rumah warga Desa Paowan Kec. Panarukan Kab. Situbondo. Peserta yang mengkuti pelatihan ini sekitar 10 orang terdiri dari Ibuibu PKK.

Sebelum melakukan Program Kreativitas Mahasiswa Pengabdian Masyarakat ini, pelaksana kegiatan melakukan pendampingan secara intensif. Melakukan persiapan tempat, alat dan bahan sekaligus materi tentang wirausaha dan pembuatan kerajinan tangan berbahan baku sampah plastik.

Kelas kreasi dalam upaya pemanfaatan sampah plastik menjadi kerajinan tangan ini akan dilaksanan melalui beberapa tahap:

a. Sosialisasi Program

Sosialisasi program dilaksanakan setelah tahap persiapan selesai yaitu dengan melakukan pertemuan dengan calon peserta yang mengikuti kelas kreasi ini dan mensosialisasikan tentang program yang akan di laksanakan.

b. Penyampaian Materi

Pada tahap ini peserta akan diberikan materi seputar kewirausahaan dan cara membuat kerajinan tangan dengan berbahan baku sampah plastik. Penyampaian materi menggunakan media power point. Materi diberikan oleh mahasiswa yang 
terlibat dalam program ini.

c. Kelas Kreasi

Kelas kreasi yaitu praktek pembuatan berbagai macam kerajinan tangan yang berbahan dasar sampah plastik dengan alat dan bahan yang sudah disediakan.

d. Pemanfaatan Hasil Kerajinan Tangan

Hasil dari kelas kreasi yang berupa kerajinan tangan kepada masyarakat umum seperti di pasar, toko-toko dan di tempat umum oleh peserta kelas kreasi sehingga bisa menciptakan peluang usaha bagi mereka untuk meningkatkan penghasilan serta melatih berwirausaha.

e. Evaluasi

Evaluasi dilakukan setelah semua tahap diatas telah terlaksana yaitu dengan meminta kritik dan saran melalui kuesioner pada peserta kelas kreasi mengenai pelaksanaan program.

\section{f. Penyusunan Laporan}

Merupakan tahap akhir pelaksanaan program yaitu menyusun dan membuat laporan hasil kegiatan.

\section{HASIL DAN PEMBAHASAN}

Pelaksanaan kegiatan Pengabdian Kepada Masyarakat ini dilakukan di rumah warga yang menyediakan berbagai peralatan lengkap, yang dapat dimanfaatkan secara optimal. Dengan adanya ketersediaan peralatan ini, diharapkan dapat memicu semangat para peserta pelatihan untuk terus mengembangkan kreativitas dan kepeduliannya terhadap lingkungan. Kelestarian lingkungan dan kreativitas merupakan dua hal yang menjadi basis program kegiatan ini.

Pemanfaatan kembali secara langsung misalnya dengan membuat produk baru yang berbahan baku limbah atau barang bekas. Pemanfaatan tersebut menerapkan prinsip-prinsip Re-use (memakai kembali), yaitu sebisa mungkin memilih barang-barang yang bisa dipakai kembali, dan Recycle (mendaur ulang), yaitu memaksimalkan pemakaian kembali material dengan teknologi daur ulang melalui industri non-formal dan industri rumah tangga yang memanfaatkan sampah menjadi barang lain yang dapat digunakan lebih lanjut. 
Botol plastik berasal dari kemasan minuman ringan mudah ditemukan karena jenis minuman tersebut banyak dijual di mana-mana. Botol-botol plastik tersebut memiliki beragam ukuran dan warna yang memiliki nilai artistik dapat dimanfaatkan untuk membentuk benda-benda bernilai guna.

Selain botol plastik, kerdus bekas, sedotan bekas, dan CD bekas juga menjadi limbah yang banyak tersedia di lingkungan. Barang bekas tersebut sebenarnya merupakan sampah nonorganis yang tidak dapat terdaur ulang oleh alam, tetapi tetap menjadi limbah karena pemakaiannya yang banyak dan belum termanfaatkan. Untuk itu pada pelaksanaan PKM ini, dibutuhkan penguasaan aspek teknik dan aspek seni dan kreativitas. Aspek teknik meliputi penggunaan sarana dan peralatan pertukangan yang mendukung praktik pembuatan lampu meja, sedangkan aspek seni dan kreativitas meliputi daya imajinasi dan kreasi untuk menghasilkan komposisi estetis dari produk tersebut. Aspek teknik akan menjadi tidak lengkap apabila tidak didukung oleh kedua aspek seni dan kreativitas tersebut. Dengan menguasai keterampilan ini diharapkan para peserta pelatihan dapat bereksplorasi dan berkreasi dalam menghasilkan benda bernilai guna baru. Keterampilan ini juga akan dapat dikembangkan menjadi sumber penghasilan baru.

Kegiatan pelatihan diikuti oleh para ibu-ibu PKK desa Paowan. Peserta program ini berjumlah 10 (sepuluh) orang, keseluruhannya wanita, dengan rentang usia 29-40 tahun.Tingkat pendidikan para peserta adalah SMP dan SMA/SMK. Peserta yang meskipun dengan rentang usia cukup besar tetapi dengan tingkat pendidikan relatif sederajat ini memudahkan pelaksanaan dalam proses pelatihan, karena terdapat kesamaan basis pengetahuan dan pengalaman dari para peserta.

Produk yang dihasilkan oleh 10 orang peserta tersebut adalah produk rumah tangga yang menggunakan botol plastik, limbah sedotan,CD bekas dan kardus sebagai bahan bakunya.

Dari bahan baku yang disediakan, para peserta memiliki kebebasan untuk membuat produk sesuai dengan bahan baku yang dipilih. Perbedaan dapat dilihat dari individu yang mengerjakan, di mana peserta yang relatif homogen tetap menghasilkan karya berbeda dalam penggunaan bahan dasar yang digunakan 
mempengaruhi komposisi hasil akhirnya. Hasil akhir dapat dikategorikan berhasil dan memuaskan, meskipun dengan latihan dan ketersediaan waktu yang lebih banyak akan dapat dicapai hasil yang lebih maksimal.

Evaluasi kegiatan meliputi keseluruhan tahap kegiatan, mulai dari tahap perencanaan, persiapan, dan pelaksanaan. Evaluasi kegiatan dilakukan bukan untuk mencari kesalahan dan kekurangan program, melainkan untuk kemajuan dan keberlanjutan program selanjutnya, dan dilakukan secara bersama oleh seluruh pelaksana kegiatan bersama dengan pihak karyawan sebagai target sasaran.

Pengukuran keberhasilan kegiatan dilakukan secara kuantitatif dan kualitatif, yaitu jumlah produk rumah tangga yang dapat diselesaikan dalam jangka waktu tertentu dan tingkat kepuasan peserta pelatihan dalam proses pengerjaan dan hasil akhir. Hasil akhir merupakan karya desain yang sifatnya subjektif, sehingga keberanian dan semangat partisipasi para peserta menjadi nilai lebih dari kegiatan pelatihan ini.

Proses persiapan dimulai dengan penjelasan maksud dan tujuan penyelenggaraan program Pengabdian Kepada Masyarakat serta manfaat yang diharapkan didapatkan oleh peserta pelatihan.

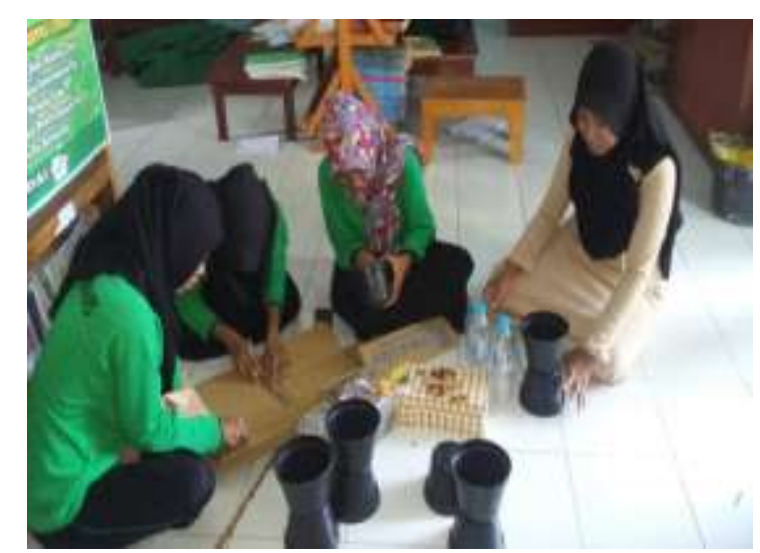

Gambar 1. Penjelasan Maksud, Tujuan, dan Proses Penyelenggaraan Progam PKM

Proses pengerjaan dimulai dengan penyediaan bahan, materi, alat, bagi para peserta. Alat dan bahan yang akan dipakai disesuaikan dengan kebutuhan dan kemudahan pengadaan, sehingga untuk selanjutnya akan dapat diperoleh dengan mudah oleh para peserta. Bahan yang digunakan adalah: (a) Botol minuman 
plastik yang telah dicuci, dilepaskan label mereknya, dan dipotong sesuai kebutuhan, (b) sendok plastik bekas, (c) sedotan, dan (d) kardus. Sedangkan peralatan listrik dan peralatan lain yang dibutuhkan adalah: (a) Fiting lampu, (b) Kabel, (c) Bohlam 5 watt, (d) Saklar, (e) Stop kontak, (f) Lem, dan (g) Alat potong.

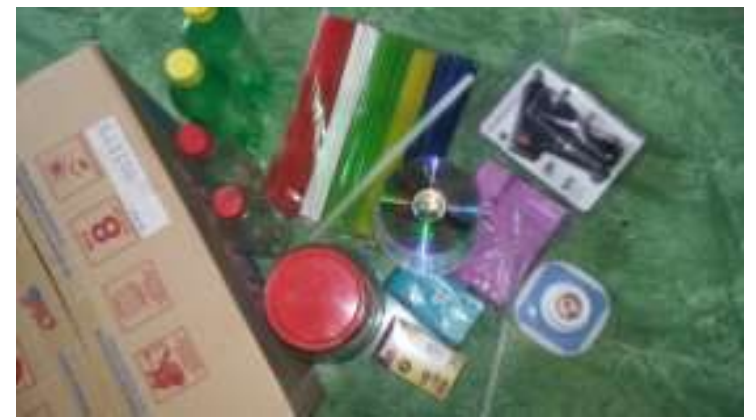

Gambar 2. Alat, Bahan, dan Material yang digunakan

Produk pertama yang dibuat dari bahan yang digunakan yaitu kardus, kabel, pitting, kaki kayu, kabel dapat dihasilkan lampu duduk yang unik dan menarih sebagai hiasan di ruangan tamu atau kamar tidur.

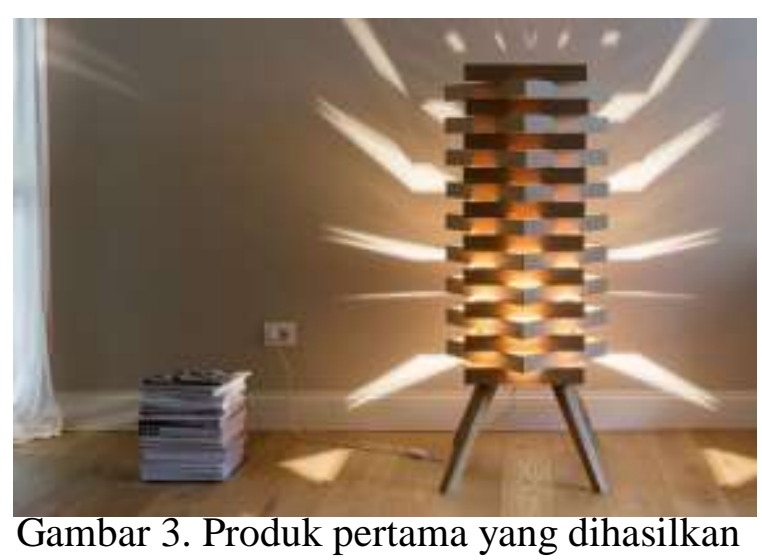

Produk kedua yang dibuat dari bahan dasar kaleng bekas, sedotan, lampu, kabel dan fitting dihasilkan lampu hias yang juga tak kalah indahnya. Dari bahan dasar toples plastik bekas, sendok plastik, lampu dan pitting dapat menghasilkan lampu duduk yang juga tak kalah menariknya dengan kedua produk yang dibuat. 


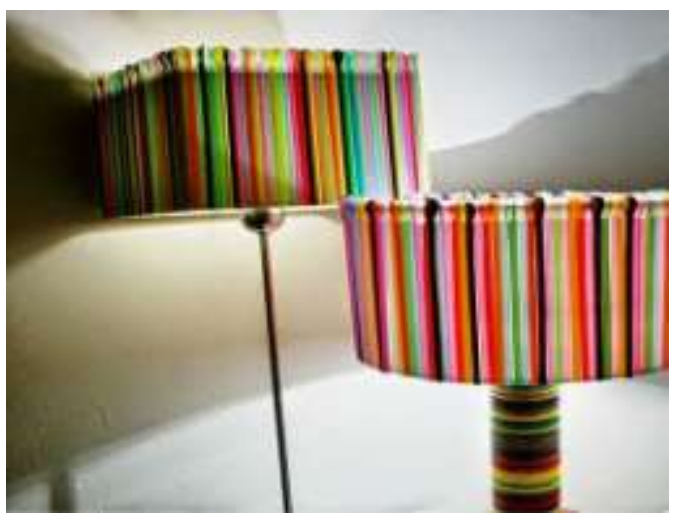

Gambar 4. Produk kedua yang dihasilkan

Produk ketiga yang dibuat dari bahan dasar toples plastik bekas, sendok plastik, lampu dan pitting dapat menghasilkan lampu duduk yang juga tak kalah menariknya dengan kedua produk yang dibuat.

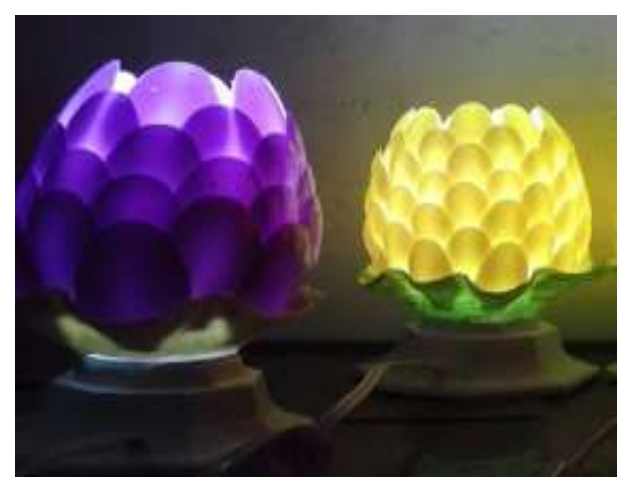

Gambar 5. Produk ketiga yang dihasilkan

Pada proses pengerjaan tentu saja masih dibutuhkan adaptasi terhadap alat dan media, yang disebabkan oleh jarangnya para peserta berinteraksi dengan alat dan media tersebut. Tetapi hal tersebut dapat diatasi dengan bimbingan langsung dari para instruktur.

Setiap peserta mampu mengerjakan 1 (satu) buah produk sesuai petunjuk pelaksanaan secara verbal dari instruktur. Keragaman hasil kreasi para peserta merupakan hasil yang positif dan sesuai dengan ekspektasi program. Pemilihan dan penentuan komposisi sumpit sekali pakai sebagai elemen estetis lampu meja menjadi hal yang menentukan dalam produk akhir.

Tidak ditemukan kegagalan hasil produksi, meskipun terdapat peserta pelatihan yang merasa kurang puas akan hasil karya pribadi dengan membandingkan dengan hasil rekan peserta yang lain. Sikap demikian bukanlah 
merupakan suatu kekurangan, melainkan menjadi pemicu akan hasil yang lebih baik di masa mendatang..

\section{KESIMPULAN DAN SARAN}

Dengan mengadakan pelatihan kelas kreasi yang memanfaatkan barang bekas yang sudah tidak digunakan menjadi barang yang bernilai guna dapat memberikan pengalaman tersendiri bagi ibu-ibu PKK untuk menambah pengetahuan tentang cara pemanfaatan barang bekas tersebut sehingga tidak hanya menghasilkan produk layak pakai tetapi juga layak jual untuk menambah barang kreasi dirumah maupun untuk menambah perekonomian keluarga.

Adapun saran pada pengabdian ini, agar materi yang diberikan sama sehingga dihasilkan produk yang seragam pula dan setiap peserta dapat membuat produk yang sama dan setelah bisa membuat produk satu dapat dilanjutkan dengan pembuatan produk yang lain.

\section{DAFTAR PUSTAKA}

Alfin, Edward. (2015). Pemanfaatan limbah rumah tangga sebagai bentuk implementas dari pendidikan lingkungan hidup. Universitas Indraprasta.

Cuffaro, Daniel. (2006). Process materials and measurements. USA: Rockport Publishers.

Ekuan, Kenji. (1984). Beberapa pemikiran tentang desain indonesia. Jakarta: CV. Rajawali.

Irawan, Bambang. (2013). Dasar-dasar desain. Depok: Griya Kreasi

https://thesainswordpress.com/2013/11/19/pemanfaatan-limbah-rumah-tanggasampah-anorganik- sebagai - bentuk-implementasi-dari-pendidikanlingkungan-hidup 